\title{
Practice-Oriented Yield Table for White Poplar Stands Growing under Sandy Soil Conditions in Hungary
}

Károly Rédei

Forest Research Institute, Püspökladány Experimental Station Farkassziget 3

Püspökladány 4150

Hungary

e-mail: redei.karoly@t-online.hu

\section{Zsolt Keserü}

Forest Research Institute,

Püspökladány Experimental Station

Farkassziget 3

Püspökladány 4150

Hungary
János Rásó

Forest Research Institute, Püspökladány Experimental Station Farkassziget 3

Püspökladány 4150 Hungary

\section{Abstract}

Background and purpose: White poplar (Populus alba L.) and its most important natural hybrid, the grey poplar (Populus x canescens SM.) are native tree species in Hungary, covering $3.2 \%$ of the forested area. Thanks to their favourite silvicultural and growth characteristics as well as the wood utilization possibilities, their present area is increasing continuously. The most important task ahead of Hungarian poplar growers is to improve the quality and to increase the quantity of poplar stands for wood production. To determine their growth rate and yield as exactly as possible, a yield table has been constructed which is based on the currently applied silvicultural practice.

Material and methods: Chapman - Richards function with three parameters was successfully used as a growth function for constructing the height growth model. The white poplar yield table was constructed from data gathered on 50 permanent and 40 temporary plots (cca. $500-1000 \mathrm{~m}^{2}$ ). The age of the stands varied between 5 and 45 years. In the course of the stand surveys the key stand characteristics were measured, and then, on the basis of data collected, were calculated such major stand structure features as the average height, diameter (DBH), volume, basal area and stem number given separately for the main (remaining), secondary (removal) and total stands per hectare.

Results and conclusion: The numerical (tabulated) yield table of normative nature presents data given to six yield classes (base age: 25 years) including the most im- portant stand structural and yield features expressing in terms of main stand, removing stand (which can be removed in tending operations) and the total stand. It is based on the Hungarian applied tending operations' practice. The published yield table has already been utilized in the field of the relevant forest inventory as well. Keywords: white poplar (Populus alba L.), Chapman Richards function, yield table, Hungary

\section{INTRODUCTION}

White poplar (Populus alba L.) and the grey poplar (Populus $x$ canescens) are native poplar species in Hungary. Their area was 65000 ha in 2006 (3.2\% of the total forested land), with a standing volume of 9.8 million $\mathrm{m}^{3}\left(163 \mathrm{~m}^{3} \mathrm{ha}^{-1}\right)$.

More than $70 \%$ of the white poplar stands can be found on calcareous sandy sites on the Danube-Tisza region. Native poplars have been regarded for several decades as weed tree species without any value for timber market. In spite of this fact about $35 \%$ of the new afforestation and artificial regeneration is carried out presently with white poplar in the mentioned region. White poplar has a rich gene pool on the sand dune region in the middle of the Great Hungarian Plain and on the bottomland of big rivers [1, 2]. In the near future, due to the establishment of national parks in these regions, considerable increases can be expected in the area of native poplars. At the same time their importance will be increasing in the large areas of marginal sites which are not suitable for hybrid poplars but can accommodate native ones. 
In the Danube-Tisza region some very important ecological factors have become unfavourable for poplar growing in the last two decades. There is no sufficient precipitation during the growing season (appr. 200-300 mm), and the rivers' control and canalisation have caused a drastic lowering of the ground-water table in many places. In such spots the water supply for poplars depends on the moisture content of soils, accumulating waters on the surface and on the water-storing capacity of soils $[3,4]$.

It should also be emphasized that white poplar is a fast-growing species which in the seedling age rises quickly form the weed competition. In the first years of the forestations established by seedling it must perform the in-line and inter-row weeding, as well as the cutting back of injured plants. During of its tending operations it is important to take into consideration, that its populations consist of trees of varied genetic value (genotypic). From the point of view of its lightdemand the fact deserves attention, that while it endeavours extremely strongly to the light, on the other hand it tolerates excellently the shade too.

The considerable white poplar afforestation of the last decades is indicated by the fact, that the 75\% (according to the area), respectively the $60 \%$ (according to the growing stock) of white poplar stands can be found on calcareous sandy sites in the Danube-Tisza region [5]. The average growing stock is $161 \mathrm{~m}^{3} / \mathrm{ha}$; the average final cutting age is 32 years.

The white poplar yield table compiled to the area of the sandy sites as regards its nature is the first in the history of the national white poplar research.
The course of the compilation, which can be programmed, makes possible enlarging the information content of the yield table and also changing its form and content.

\section{MATERIAL AND METHODS}

The white poplar yield table was constructed from data gathered on 50 permanent and 40 temporary plots (cca. 500-1000 m²) located in stands in the sandy ridges between the rivers Danube and Tisza (Figure 1 ). The age of the pure stands owned by state varies between 5 and 45 years and they have been managed on base of growth and silvicultural model for white poplar stands [3].

In the course of the stand surveys the key stand characteristics were measured, and then, on the basis of data collected, were calculated such major stand structure features as the average height, diameter $(\mathrm{DBH})$, volume, basal area and stem number given separately for the main (remaining), secondary (removal) and total stands per hectare. Stem volume was estimated by the following volume function [6]:

$v=10^{-s} d^{2} h^{\prime}(h /[h-1.3])^{2}[-0.4236 d h+12.43 d+4.6 h+3298]$

where $v$ is stem volume $\left(\mathrm{m}^{3}\right), d$ is diameter at breast height $(\mathrm{cm})$, and $h$ is tree height $(\mathrm{m})$. The regression analysis have been computed by the ANOVA statistical programme.

In the USA, South Africa and many other countries, the site index, site class or yield class of a stand is usually defined as the mean height of the dominants and codominants [7-10], at a reference age, which is closely




linked with the rotation age. In Germany, the site index, which replaced the earlier site class concept, is defined as the regression height of the quadratic mean diameter of the 100 thickest trees per hectare at a reference age which is usually 100 years [11]. A much lower reference age is used for fast-growing stands and plantations, for example, 25 years for black locust (Robinia pseudoacacia L.) [12], and also 25 years were chosen for white poplar to construct the new yield table.

In Hungary the Chapman - Richards function [13] is the most frequently used function in the yield - (site -) dependent height growth model. It has three parameters $\mathrm{a}, \mathrm{b}$ and $\mathrm{c}$, which control the asymptote, slope, and the location of the function's inflection point. On base of this function a guide curve was fitted to the distribution of the average heights of main stands, plotted over age. This curve was used to generate a family of yield class curves on base of the reference age. The expected height values of the main stands at the reference age according to the yield classes are: $24.2 \mathrm{~m}, 21.6 \mathrm{~m}, 19.0$ $\mathrm{m}, 16.4 \mathrm{~m}, 13.8 \mathrm{~m}$ and $11.2 \mathrm{~m}$. According to the fitted guide curve and to the reference age (100\%) a percentage value could be calculated at any ages and for any yield classes. The authors' yield table was constructed using the following formulas and coefficients (detailed dataset can be available at the authors):

\section{Age of stand (A)}

2. $H_{m}=$ average height of main (remaining) stand (height of dominant and co-dominant trees) in $\mathrm{m}$ :

$$
H_{-}=1.21592 \times\left(1-e^{-00023 s}\right)^{20.03 *}
$$

3. $\mathrm{D}_{\mathrm{m}}=$ average $\mathrm{DBH}$ of main (remaining) stand in $\mathrm{cm}$ :

$D_{n}=1.58356+0.73502 \times H_{n}+0.01571 \times H_{m}^{2}$

with $\mathrm{R}^{2}=0.886$

4. $\mathrm{V}_{\mathrm{m}}=$ volume of main (remaining) stand in $\mathrm{m}^{3} \mathrm{ha}^{-1}$ :

$$
V_{n}=B A_{m} \times H \times F
$$

where $H \times F=$ form-height quotient

$$
H \times F=1.96791+0.40778 \times H_{\text {r }}
$$

with $\mathrm{R}^{2}=0.923$

5. $B A_{m}=$ basal area of main (remaining) stand in $m^{2} h^{-1}$ :

$$
B A_{n}=\frac{D_{m}^{2} \times \Pi}{4 \times 10000} \times N_{n}
$$

6. $\mathrm{N}_{\mathrm{m}}=$ stem number of main (remaining) stand in $h a^{-1}$ :

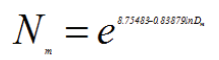

with $\mathrm{R}^{2}=0.826$

7. $\mathrm{H}_{\mathrm{r}}=$ average height of removal stand in $\mathrm{m}$ :

$$
H_{r}=0.7 \times H_{m}
$$

8. $D_{r}=$ average $D B H$ of removal stand in $\mathrm{cm}$ :

$$
D_{r}=0.7 \times D_{m}
$$

9. $\mathrm{V}_{\mathrm{r}}=$ volume of removal stand in $\mathrm{m}^{3} h \mathrm{a}^{-1}$ :

$$
V_{r}=B A_{r} \times H \times F_{n}
$$

10. $B A_{r}=$ basal area of removal stand in $m^{2} h^{-1}$ :

$$
B A_{r}=\frac{D_{r}^{2} \times \Pi}{4 \times 10000} \times N \text {. }
$$

11. $\mathrm{N}_{\mathrm{r}}=$ stem number of removal stand computing from reduction of stem number of main crop in five year intervals in $h^{-1}$

12. $\mathrm{H}_{\mathrm{t}}=$ average height of total stand in $\mathrm{m}$ :

$$
\begin{aligned}
& H_{t}=1.14174+1.02809 \times H_{m} \\
& \text { with } \mathrm{R}^{2}=0.917
\end{aligned}
$$

13. $D_{t}=$ average $D B H$ of total stand in $\mathrm{cm}$ :

$$
B A_{m}=\frac{D_{m}^{2} \times \Pi}{4 \times 10000} \times N_{m}
$$

14. $\mathrm{BA}_{\mathrm{t}}=$ basal area of total stand in $\mathrm{m}^{2} \mathrm{xha}^{-1}$ :

$$
B A_{t}=B A_{m}+B A_{r}
$$

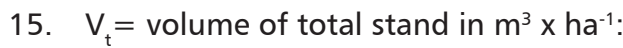

$$
V_{t}=V_{n}+V_{\text {, }}
$$

16. $\mathrm{N}_{\mathrm{t}}=$ stem number of total stand in $\mathrm{ha}^{-1}$ :

$$
N_{t}=N_{n}+N_{\text {, }}
$$

17. Cumulative volume of intermediate cuttings $=\Sigma$ total volume of removing stands in $\mathrm{m}^{3}$ $h a^{-1}$.

18. Cumulative total volume $(\Sigma V)=$ volume of total 
stand in age $A+$ volume of removing stand in age $A-5$ in $m^{3} h a^{-1}$.

19. Mean annual increment of cumulative total volume $=(\Sigma V) \times A^{-1}$ in $m^{3} h a^{-1} y r^{-1}$. Due to the yield table construction followed by the authors, the culmination of the mean annual volume increment in each yield class can be found at the reference age.

20. Current increment of cumulative total volume $=$ one year increment of $(\Sigma V)$ in five year intervals in $m^{3} h a^{-1} y r^{-1}$.

\section{RESULTS}

The numerical (tabulated) yield table of normative nature presents data given to six yield classes (base age: 25 years) including the most important stand structural and yield features expressing in terms of

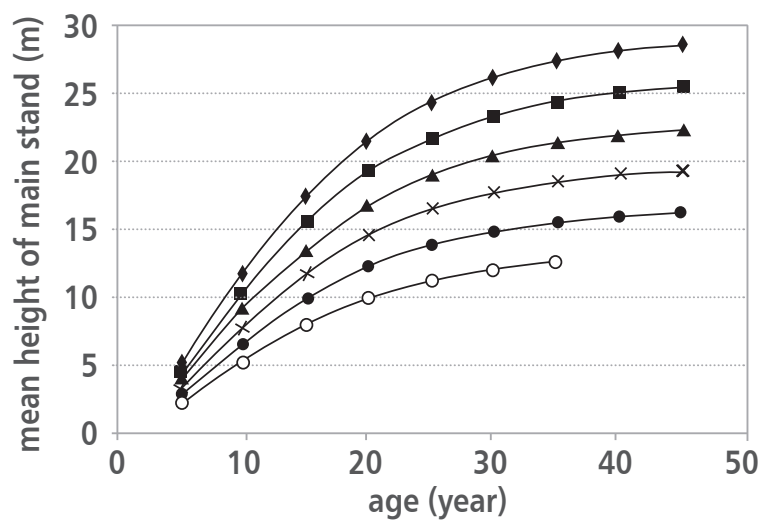

\section{- Yield class I \\ - Yield class II \\ $\_$Yield class III \\ * Yield class IV \\ - Yield class V \\ -o- Yield class VI}

a) Mean height yield class indices for main stand

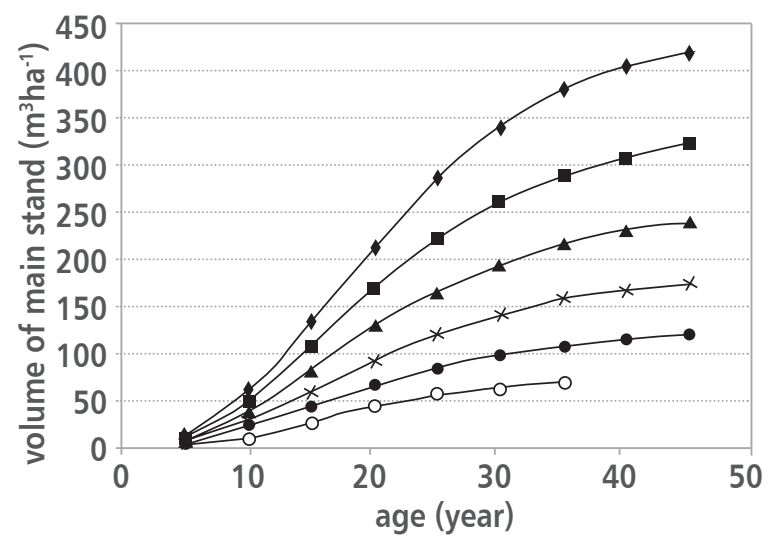
$\rightarrow$ Yield class I
- Yield class II
$\leftarrow$ Yield class III
* Yield class IV
- Yield class V
-o- Yield class VI
c) Volume yield class indices for main stand

main stand, removing stand (which can be removed in tending operations) and the total stand. It is based on the currently applied silvicultural practice [3]. The data are given form 5 to years 45 (Table 1). Figure 2.a to 2.f show the height, DBH, volume and stem number indices for main stand as well as the total volume and the mean annual increment of total volume indices in function of age and yield class.

When using the yield table for determining the actual volume per ha $\left(\mathrm{V}_{\text {act }}\right)$ of a stand, a basal area ratio is to be recommended:

$$
V_{\alpha t}=V_{t w} \times B A_{\alpha t} B A^{-1}{ }_{t w}
$$

where:

$\mathrm{V}_{\text {tab }}=$ volume of the stand by yield table according to the age and yield class,

$\mathrm{BA}_{\text {act }}=$ actual basal area of the stand per ha,

$\mathrm{BA}_{\text {tab }}=$ basal area by yield table according to the age and yield class of the stand.
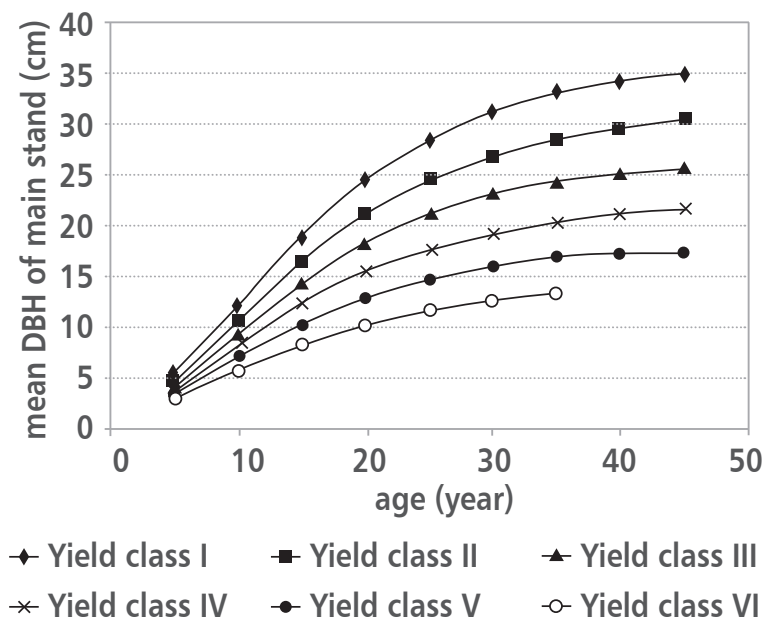

b) Mean DBH yield class indices for main stand

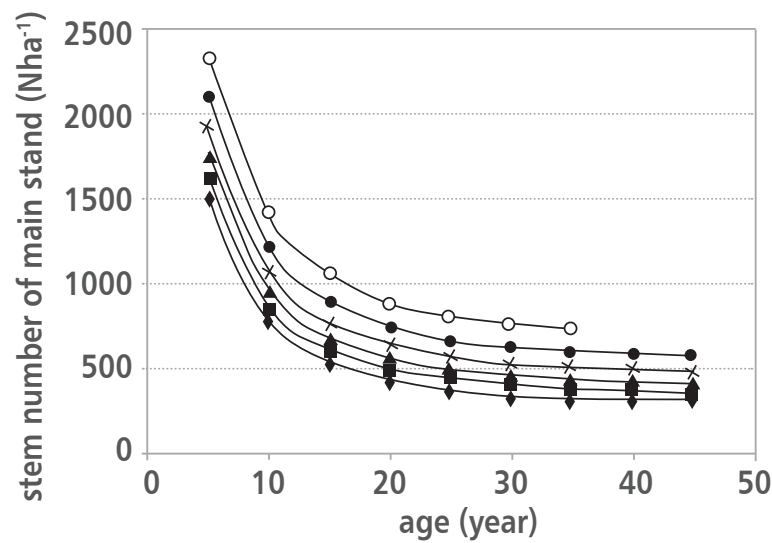
$\rightarrow$ Yield class I
- Yield class II
- Yield class III
* Yield class IV
- Yield class V
-o- Yield class VI
d) Stem number yield class indices for main stand 


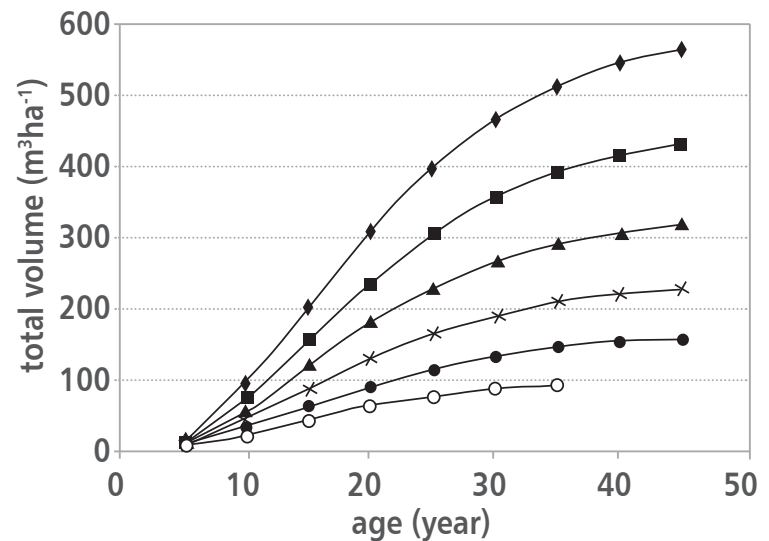

$\rightarrow$ Yield class I $\rightarrow$ - Yield class II $\rightarrow$ Yield class III
$*$ Yield class IV $\rightarrow$ Yield class V $\rightarrow$ - Yield class VI
e) Total volume yield class indices

FIGURE 2

White poplar stand structure factors in function of age and yield class

\section{DISCUSSION AND CONCLUSIONS}

Growth is a biological process, which is defined and measured as the change in volume and other size parameters as a function of age. Yield quantifies the volume (or weight) of the whole stand or of a single tree, which is potentially available at the time of harvesting. In order to obtain a biologically meaningful estimate for growth, the volume should reflect the total, rather than merchantable stand volume, although the latter is required for management inventories.

The published empirical yield table is the first one for white poplar stands in the international literature based on Chapman - Richards function used for yield - dependent height growth model. This type of yield tables supposedly applies to "average" rather than full stocking. In other words, an empirical yield table applies only to the average density levels found on the sample plots used.

Empirical yield tables provide few advantages over full stocking yield tables; the principal idea behind their construction was that the resultant tables should more closely approximate realizable yields under operational forest management than would the values from full stocking yield tables [8]. In spite of this fact the modern growth and yield modelling techniques do not rely on either "average" or full stocking density concepts, but, rather, include density as a dynamic part of the standprojection system. Such growth and yield models are commonly termed variable-density tables (or equations).

In the last decades, growth models focussed on stand level data have gradually been replaced by stand

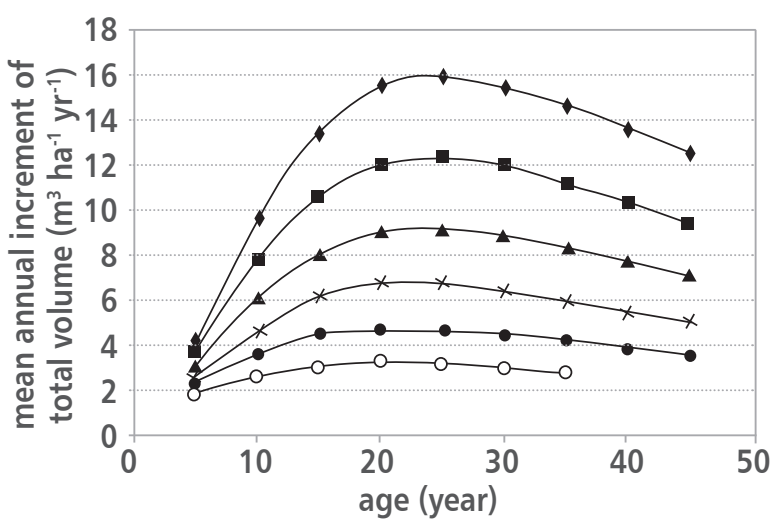

\section{$\rightarrow$ Yield class I $\rightarrow$ Yield class II $\rightarrow$ Yield class III * Yield class IV $\bullet$ - Yield class V $\quad$ - - Yield class VI \\ f) Mean annual increment of total volume yield class indices}

growth models that predict stem number frequencies and individual-tree growth models [11]. In spite of this fact yield tables will remain very useful tools for forest management and forest inventory in the future.

The published yield table can be widely utilized in the following fields of the Hungarian white poplar management and the relevant forest inventory:

- appraisal of statistical nature of the white poplar stands,

- harvest scheduling of white poplar stands, implementing the volume estimations,

- elaborating or further developing silvicultural (tending operation) models for white poplar stands,

- elaborating and explaining the guidelines of the local tree species policy, and

- national analysis related to the growing of white poplar stands.

To improve the yield models for white poplar stands is to be considered as a continuous task in the future, too.

\section{Acknowledgements}

The authors gratefully acknowledge the valuable comments on the manuscript made by Prof. Dr. $\mathrm{H}$. Röhle, Chair of Forest Growth Science, Dresden University of Technology (TUD), Tharandt, Germany. The authors would like to thank Mr. E. Linkevicius also from the Chair of Forest Growth Science, for his assistance. Thanks also to Dr. D. Butler Manning of the Chair of Eastern European Forestry and Forest Products of the Dresden University of Technology for proofreading the English. 


\begin{tabular}{|c|c|c|c|c|c|c|c|c|c|c|c|c|c|c|c|c|c|c|c|c|c|c|c|c|c|c|c|c|c|c|c|c|}
\hline \multirow{3}{*}{ 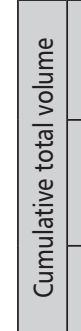 } & \multicolumn{2}{|c|}{ 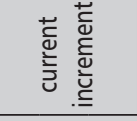 } & i) & & & ָֻ & $\stackrel{\bar{\sim}}{\bar{N}}$ & $\stackrel{m}{\grave{N}}$ & $\stackrel{?}{x}$ & $\stackrel{\stackrel{p}{m}}{m}$ & 吕 & ثึ & $\bar{f}$ & & : & $\stackrel{?}{\stackrel{9}{E}}$ & $\mid \begin{array}{c}\tilde{0} \\
6 \\
-1\end{array}$ & $\mid \begin{array}{c}n \\
6 \\
6\end{array}$ & $\begin{array}{l}\stackrel{\sim}{n} \\
\stackrel{m}{m}\end{array}$ & $\begin{array}{l}\circ \\
0\end{array}$ & 임. & $\hat{\dot{\gamma}}$ & $\stackrel{\sim}{n}$ & $\stackrel{0}{0}$ & $\dot{\sigma}$ & $\dot{i}$ & $\stackrel{9}{=}$ & ğ & $m$ & in & $\begin{array}{l}\dot{v} \\
\dot{m}\end{array}$ & $\sim$ \\
\hline & \multicolumn{2}{|c|}{ 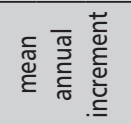 } & $\pi$ & & $\check{F}$ & $\hat{\sigma}$ & $\stackrel{n}{m}$ & 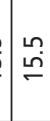 & 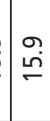 & $\begin{array}{l}\stackrel{n}{n} \\
\text { nn }\end{array}$ & 导 & $\begin{array}{l}\stackrel{0}{m} \\
\stackrel{m}{*}\end{array}$ & $\begin{array}{l}0 \\
\stackrel{1}{I}\end{array}$ & & $\begin{array}{c}\dot{\omega} \\
\dot{m}\end{array}$ & $\stackrel{\infty}{\stackrel{\infty}{r}}$ & $\mid \begin{array}{l}0 \\
0 \\
0\end{array}$ & 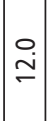 & $\stackrel{m}{\sim}$ & $\stackrel{9}{\check{E}}$ & $\stackrel{\simeq}{=}$ & $\stackrel{0}{0}$ & nم & $\bar{m}$ & $i \bar{c}$ & $\dot{0} \bar{\infty}$ & $\vdots \bar{\sigma}$ & 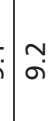 & $\begin{array}{l}0 \\
\infty\end{array}$ & $\begin{array}{l}+ \\
\infty\end{array}$ & $\stackrel{i}{\wedge}$ & in \\
\hline & \multicolumn{2}{|l|}{$\begin{array}{l}\stackrel{0}{\xi} \\
\frac{5}{9}\end{array}$} & $i$ & & $\bar{\sim}$ & ลิ & $\stackrel{m}{\stackrel{\sim}{N}}$ & के & $\stackrel{\infty}{m}$ & 足 & $\frac{m}{i n}$ & 年 & 望 & & $\stackrel{\infty}{-}$ & $\stackrel{\infty}{\sim}$ & 哭 & 号 & 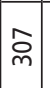 & $\stackrel{n}{m}$ & సิ & $\frac{0}{\gamma}$ & 尚 & $\dddot{6}$ & $\bar{\varphi}$ & $\stackrel{N}{\sim}$ & $\infty$ & 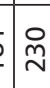 & $\widehat{\underline{\omega}}$ & $\stackrel{m}{\sim}$ & $\frac{0}{m}$ & $\bar{m}$ \\
\hline \multicolumn{3}{|c|}{ 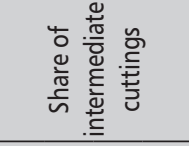 } & $0^{\circ}$ & & 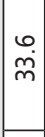 & $\stackrel{m}{\stackrel{m}{m}}$ & $\begin{array}{l}0 \\
\stackrel{\sim}{m}\end{array}$ & กิ & $\stackrel{\infty}{\stackrel{\infty}{N}}$ & 㐫 & ì & ڤั & $\mid \begin{array}{c}\stackrel{n}{\sim} \\
\stackrel{\sim}{\sim}\end{array}$ & & $\begin{array}{l}\infty \\
\dot{m} \\
\dot{m}\end{array}$ & $\mid \begin{array}{l}\infty \\
0 \\
0 \\
m\end{array}$ & $\underset{m}{\stackrel{m}{m}}$ & Dे. & $\mid \begin{array}{l}0 \\
\grave{N}\end{array}$ & $\mid$ & $\overline{\dot{\omega}}$ & 岂 & 孞 & $\stackrel{\overbrace{}}{~}$ & 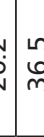 & $\dot{b}$ & ఇָ & $\stackrel{n}{\stackrel{n}{N}}$ & $\begin{array}{l}n \\
\stackrel{1}{0} \\
\stackrel{0}{N}\end{array}$ & 离 & $\begin{array}{l}\stackrel{n}{n} \\
\stackrel{n}{n}\end{array}$ & $\stackrel{\sim}{\stackrel{\sim}{N}}$ \\
\hline \multicolumn{3}{|c|}{ 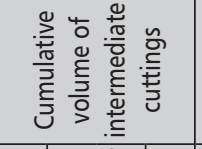 } & & & N & 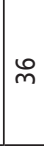 & 8 & శ్ & $\Xi$ & 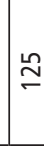 & 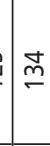 & 専 & 过 & & 6 & ని & in & ㅇ & 曲 & เू & 으 & 응 & 응 & 6 & $\curvearrowright$ & v & ? & 0 & $\pi$ & $\stackrel{\circ}{2}$ & হ & $\bar{\infty}$ \\
\hline & \multicolumn{2}{|l|}{ है } & 正 & & 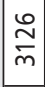 & 용 & $\stackrel{\infty}{\gtrless}$ & ñ & $\stackrel{m}{q}$ & $\bar{\infty}$ & 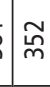 & 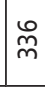 & 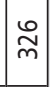 & & 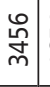 & 产 & $\mid \begin{array}{l}\infty \\
\infty \\
\infty\end{array}$ & 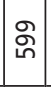 & $\mid \begin{array}{c}\infty \\
\stackrel{\infty}{\sigma}\end{array}$ & 忞 &  & $\begin{array}{l}\stackrel{9}{2} \\
m\end{array}$ & 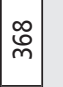 & $\begin{array}{l}\hat{n} \\
\infty \\
m\end{array}$ & $\stackrel{\infty}{\infty}$ & : & $\frac{10}{6}$ & กิ & 官 & 占 & $\stackrel{\dot{q}}{m}$ & $\underset{\forall}{\mathscr{F}}$ \\
\hline & \multicolumn{2}{|l|}{ 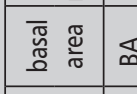 } & 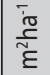 & & $\begin{array}{l}m \\
n \\
n\end{array}$ & $\stackrel{\dot{v}}{\ddot{q}}$ & $\begin{array}{l}\text { Ln } \\
\infty \\
\infty\end{array}$ & 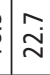 & 哭 & $\stackrel{\sim}{\infty}$ & ฉั & ì & $\frac{m}{m}$ & & $\stackrel{\leftrightarrow}{+}$ & $\stackrel{n}{=}$ & \begin{tabular}{|l|}
$\infty$ \\
$\stackrel{n}{\sim}$ \\
\end{tabular} & $\mid \begin{array}{c}m \\
a \\
\sigma\end{array}$ & 올 & $\begin{array}{l}\infty \\
\ddot{\nu} \\
\end{array}$ & 울 & $\begin{array}{l}\infty \\
\stackrel{\infty}{\sim} \\
\stackrel{2}{*}\end{array}$ & 它 & in & & $\begin{array}{l}\circ \\
\dot{n} \\
\stackrel{m}{m}\end{array}$ & $\ddot{\sigma}$ & $\begin{array}{l}m \\
\infty \\
-\end{array}$ & $\begin{array}{l}\infty \\
\sigma \\
\sigma\end{array}$ & $\begin{array}{l}\infty \\
\dot{0} \\
\dot{N}\end{array}$ & $\stackrel{\nabla}{\grave{n}}$ & $\stackrel{\infty}{\grave{N}}$ \\
\hline & $\frac{\stackrel{\varrho}{5}}{\frac{\xi}{9}}$ & 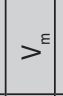 & 疍 & & $\bar{\sim}$ & 8 & 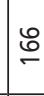 & $\stackrel{\mathscr{m}}{\sim}$ & 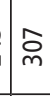 & 鬲 & ${ }_{m}^{\infty}$ & $\bar{q}$ & $\stackrel{\stackrel{\sim}{\dddot{f}}}{\not}$ & & $\stackrel{\infty}{-}$ & $\bar{\pi}$ & 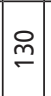 & $\stackrel{\infty}{\infty}$ & $\hat{\sim}$ & $\underset{\sim}{\sim}$ & શิ & $\frac{\nabla}{m}$ & $\stackrel{\stackrel{\sim}{m}}{\sim}$ & $\underline{6}$ & $=$ & గু & $\mathscr{I}$ & 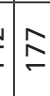 & 䓌 & $\underset{N}{\approx}$ & 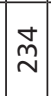 & $\stackrel{\sim}{\sim}$ \\
\hline & 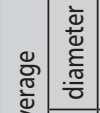 & 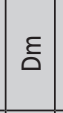 & छુ & & $\dot{f}$ &  & 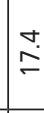 & $\stackrel{\sim}{\sim}$ & $\stackrel{0}{\grave{N}}$ & 官 & $\stackrel{\infty}{\stackrel{\infty}{m}}$ & $\overline{\dot{m}}$ & $\begin{array}{l}0 \\
\stackrel{i}{i} \\
m\end{array}$ & & $\stackrel{m}{+}$ & नें & \begin{tabular}{|l}
$m$ \\
$\stackrel{m}{n}$
\end{tabular} & 孞 & 엄 & $\mid$ & $\begin{array}{c}m \\
\infty \\
\sim\end{array}$ & 足 & $\left|\begin{array}{c}n \\
\dot{m} \\
m\end{array}\right|$ & $=\mid \begin{array}{l}0 \\
m\end{array}$ & $? \begin{array}{l}m \\
\infty\end{array}$ & $\stackrel{n}{0} \stackrel{m}{m}$ & $\stackrel{\text { nn }}{\stackrel{n}{=}}$ & ? & $\hat{N}$ & $\stackrel{\check{d}}{\dot{\sim}}$ & ह். & $\stackrel{\hat{n}}{\sim}$ \\
\hline & 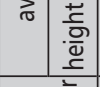 & 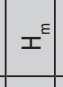 & $\varepsilon$ & $\mid \begin{array}{l}\frac{\hat{\sigma}}{0} \\
\frac{\pi}{0} \\
\frac{\partial}{0}\end{array}$ & $\hat{m}$ & $\begin{array}{l}\infty \\
0 \\
0\end{array}$ & $\ddot{6}$ & ì. & $\begin{array}{l}\infty \\
\ddot{\sim} \\
\ddot{\sim}\end{array}$ & 苫 & $\begin{array}{l} \\
\stackrel{\infty}{0} \\
\stackrel{0}{0}\end{array}$ & $\begin{array}{l}0 \\
i \\
\end{array}$ &  & 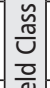 & $\stackrel{\sim}{m}$ & ตุ & $\stackrel{f}{\dot{f}}$ &  & 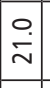 & \begin{tabular}{|l|}
$\mathbf{N}$ \\
\end{tabular} & $\begin{array}{l}\infty \\
\stackrel{\infty}{\sim} \\
\end{array}$ & \begin{tabular}{|l|}
\multirow{2}{*}{} \\
$\stackrel{\text { f }}{\sim}$ \\
\end{tabular} & 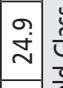 & 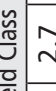 & & 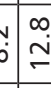 & $\overline{0}$ & $\begin{array}{l}m \\
\infty \\
\infty \\
-\end{array}$ & $\begin{array}{l}\infty \\
\stackrel{\infty}{-}\end{array}$ & $\begin{array}{l}\infty \\
\dot{i} \\
\dot{N}\end{array}$ & $\begin{array}{l}\dot{v} \\
\dot{\sim} \\
\end{array}$ & $\stackrel{\infty}{i}$ \\
\hline & 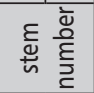 & $=$ & ¿ृ & $\simeq \simeq$ & 离 & $\overline{6}$ & 㐫 & $\stackrel{8}{0}$ & ก & Nి & 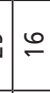 & 으 & $n$ & & $\begin{array}{l}\text { వ్ } \\
\infty\end{array}$ & 过 & 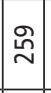 & $\stackrel{\cong}{\subsetneq}$ & in & $\approx$ & g & $=$ & 0 & 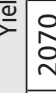 & & గొ & $\stackrel{\mathscr{N}}{\cong}$ & $\sigma$ & $\stackrel{n}{m}$ & $\bar{\sim}$ & $\cong$ & $\infty$ \\
\hline & 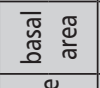 & $\mathbb{\infty}^{E}$ & \begin{tabular}{|l|}
$\bar{\tau}$ \\
$\bar{\tau}$ \\
$\underline{\tilde{\tau}}$ \\
\end{tabular} & & $\stackrel{\infty}{\sim}$ & $\stackrel{\nabla}{+}$ & $\stackrel{m}{m}$ & $\stackrel{\text { i }}{i}$ & $\stackrel{6}{-}$ & $=$ & 15 & นุ & ma & & $\cong$ & $\begin{array}{l}0 \\
m \\
m\end{array}$ & \begin{tabular}{|l|} 
\\
$\sim$ \\
\end{tabular} & i & $\stackrel{m}{-}$ & ஜே & $\ddot{0}$ & ठ். & o & 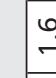 & $\stackrel{0}{1}$ & 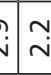 & $\stackrel{0}{-}$ & 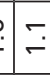 & 0 & in & $\begin{array}{l}m \\
0 \\
0\end{array}$ & N \\
\hline & & & 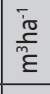 & & $r$ & ని & m & $\stackrel{\sim}{N}$ & 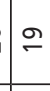 & $\neq$ & $\sigma$ & 0 & เn & & 0 & $\approx$ & $\ddot{\sim}$ & $\mathscr{-}$ & $\Xi$ & 으 &  & $\infty$ & $m$ & 6 & 7 & $=1$ & $\stackrel{\Xi}{\Xi}$ & 음 & 1 & Ln & $m$ & 10 \\
\hline & 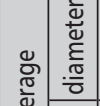 & 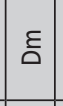 & छ & & $\stackrel{\infty}{m}$ & \begin{tabular}{|l}
$n$ \\
$\infty$ \\
$\infty$
\end{tabular} & $\stackrel{m}{m}$ & $\bar{\pi}$ & : & $\stackrel{\frac{9}{\sim}}{\bar{n}}$ & $\stackrel{\sim}{\sim}$ & $\overline{\dot{d}}$ & $\begin{array}{l}0 \\
\dot{d} \\
\end{array}$ & & $\stackrel{n}{m}$ & $\stackrel{0}{r}$ & $\stackrel{0}{\stackrel{0}{=}}$ & $\mid \begin{array}{l}\stackrel{9}{+} \\
\dot{+}\end{array}$ & $\stackrel{m}{\stackrel{m}{=}}$ & $\begin{array}{l}\circ \\
\stackrel{-}{\circ} \\
\end{array}$ & $\check{\check{D}}$ & $\mid \begin{array}{l}\infty \\
\stackrel{2}{\sim} \\
\mid\end{array}$ & $\stackrel{n}{\sim}$ & m & $\begin{array}{l}y \\
\vdots \\
\end{array}$ & $\dot{0}$ & $\stackrel{\infty}{\stackrel{\infty}{\simeq}}$ & $\begin{array}{l}\infty \\
\dot{I}\end{array}$ & $\begin{array}{l}\tilde{v} \\
\underline{6}\end{array}$ & 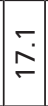 & $\stackrel{m}{\stackrel{m}{\sim}}$ & $\stackrel{-}{\infty}$ \\
\hline & 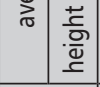 & & $\varepsilon$ & & i & $\bar{\infty}$ & $\check{\check{C}}$ & $\stackrel{\circ}{i n}$ & ఝ & $\stackrel{\sim}{\infty}$ & $\stackrel{\circ}{\circ}$ & Ö. & \begin{tabular}{|l|} 
\\
g్
\end{tabular} & & $\stackrel{\circ}{m}$ & $\stackrel{\sim}{\sim}$ & \begin{tabular}{l|}
$\infty$ \\
0 \\
0
\end{tabular} & $\begin{array}{l}m \\
m \\
m\end{array}$ & $\ddot{i}$ & ְ̋ & $\stackrel{0}{=}$ & 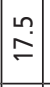 & $\stackrel{\infty}{\stackrel{\infty}{=}}$ & $\stackrel{6}{2}$ &  & $\begin{array}{l}\dot{0} \\
\dot{0}\end{array}$ & $\stackrel{\check{\varepsilon}}{\bar{g}}$ & $\stackrel{m}{m}$ & $\stackrel{m}{\dot{p}}$ & $\begin{array}{l}\stackrel{g}{+} \\
\dot{+}\end{array}$ & $\begin{array}{l}\dot{t} \\
\stackrel{\leftrightarrow}{+}\end{array}$ & $\begin{array}{l}\stackrel{\varphi}{\leftrightarrow} \\
\stackrel{\ln }{ }\end{array}$ \\
\hline \multirow{5}{*}{ 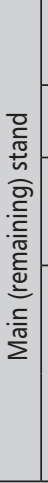 } & 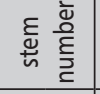 & $z^{E}$ & i & & & $\stackrel{\infty}{\aleph}$ & ñ & $\ddot{q}$ & $\bar{\infty}_{m}^{\bar{m}}$ & గ్గñ & $\mid \begin{array}{l}m \\
m\end{array}$ & $\underset{m}{\stackrel{\mathscr{m}}{m}}$ & $\frac{\varrho}{m}$ & & 它 & $\begin{array}{l}\infty \\
\stackrel{\infty}{\infty} \\
\infty\end{array}$ & 尺े & $\mid \begin{array}{c}\infty \\
⿱ 亠 乂\end{array}$ & જి & 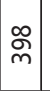 & $\stackrel{\Omega}{\stackrel{9}{m}}$ &  & 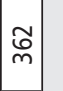 & 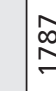 & : & గิ & กิ & \% & 年 & ঙे & $\underset{\mathcal{F}}{\mathbb{Z}}$ & $\frac{d}{8}$ \\
\hline & 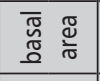 & $\overleftarrow{\Phi}^{E}$ & 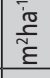 & & $?$ & $\bar{\sigma}$ & 듬 & ì & 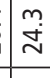 & $\bar{\AA}$ & शे & m. & 엄 & & & ?ִ & \begin{tabular}{|l|} 
\\
\\
\end{tabular} & $\stackrel{+}{\stackrel{2}{*}}$ & 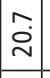 & $\stackrel{\Omega}{\sim}$ & $\stackrel{+}{\stackrel{d}{\sim}}$ & 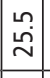 & \begin{tabular}{|l|}
$\tilde{N}$ \\
$\stackrel{0}{0}$ \\
\end{tabular} & $\stackrel{9}{\sim}$ & $\begin{array}{ll} & \infty \\
& 0 \\
\end{array}$ & $\begin{array}{l}0 \\
\dot{0}\end{array}$ & 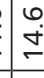 & $\stackrel{1}{\frac{1}{2}}$ & r. & $\begin{array}{l}m \\
\dot{0} \\
\text { in }\end{array}$ & $\check{\bar{\sim}}$ & $\frac{\underline{6}}{n}$ \\
\hline & $\frac{\stackrel{\varrho}{\Xi}}{0}$ & 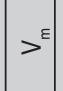 & 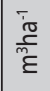 & & 2 & $\overline{6}$ & $\stackrel{\mathscr{m}}{n}$ & $\stackrel{\bar{N}}{\bar{N}}$ & $\stackrel{\infty}{\infty} \underset{\sim}{\infty}$ & $\bar{m}$ & 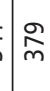 & 号 & $\overline{\mathcal{F}}$ & & $\simeq$ & 守 & 응 & 8 & $\underset{\sim}{\mathbb{N}}$ & 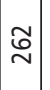 & ஓ্ণী & 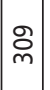 & $\underset{m}{\mathbb{m}}$ & ㅇ & $2 \stackrel{\circ}{m}$ & $\begin{array}{c}n \\
\infty\end{array}$ & $\stackrel{\infty}{\sim}$ & 6 & $\stackrel{\circ}{\circ}$ & $\stackrel{\bar{N}}{\sim}$ & $\overline{\tilde{m}}$ & I \\
\hline & \multirow{2}{*}{ 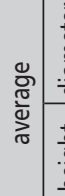 } & ص & દ્ & & นึ & $\stackrel{\sim}{\simeq}$ & 웅 & 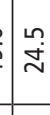 & $\begin{array}{l}n \\
\infty \\
\infty\end{array}$ & $\frac{m}{m}$ & $\stackrel{\sim}{m}$ & $\stackrel{m}{\dot{p}}$ & $\mid \begin{array}{c}n \\
\stackrel{m}{m}\end{array}$ & & 이 & $\begin{array}{l}0 \\
0 \\
0\end{array}$ & $\mid \begin{array}{l}0 \\
\dot{0} \\
-\end{array}$ & $\mid \frac{m}{\sim}$ & 离 & $\bar{\lesssim}$ & $\widehat{\infty}$ & จें & 官 & $\stackrel{\sim}{q}$ & \begin{tabular}{l|l}
$\sigma$ \\
$f$
\end{tabular} & 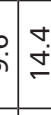 & $: \begin{array}{l}m \\
\infty \\
\infty\end{array}$ & $\frac{N}{n}$ & $\stackrel{-}{\sim}$ & $\stackrel{\text { I }}{\text { I }}$ & 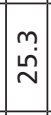 & 㐫 \\
\hline & & $I^{\varepsilon}$ & $\varepsilon$ & & $\dot{\sigma}$ & $\stackrel{一}{=}$ & $\stackrel{m}{\check{n}}$ & 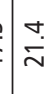 & $\stackrel{\sim}{\sim}$ & 웅 & $\stackrel{\sim}{\sim}$ & $\stackrel{0}{\infty}$ & $\left|\begin{array}{c}\vdots \\
\stackrel{d}{\infty} \\
\sim\end{array}\right|$ & & $\stackrel{\sim}{\sim}$ & m. & $\begin{array}{l}\text { 苟 } \\
\stackrel{n}{n}\end{array}$ & $\bar{\sigma}$ & $\mid \stackrel{\leftrightarrow}{\grave{N}}$ & $\begin{array}{l}\sim \\
\tilde{n} \\
\sim\end{array}$ & $\stackrel{m}{\stackrel{m}{\sim}}$ & $\mid \begin{array}{r}\mid \\
\dot{\sim}\end{array}$ & 离 & $\hat{m}$ & $\bar{\sigma}$ & $\stackrel{n}{\stackrel{n}{m}}$ & 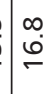 & $\stackrel{\circ}{\circ}$ & ণ & $\frac{m}{\grave{N}}$ & $\frac{\varrho}{\grave{N}}$ & $\stackrel{m}{N}$ \\
\hline \multicolumn{2}{|r|}{ 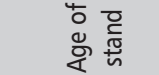 } & & $>$ & & n & 으 & $\stackrel{n}{\circ}$ & i & $\stackrel{\sim}{\sim}$ & m & $\dot{p}$ & 앙 & + & & $\ln$ & 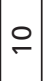 & $\stackrel{\llcorner}{\sim}$ & 이 & $\stackrel{\llcorner}{\sim}$ & m & 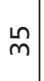 & 암 & f & เก & $1 \%$ & 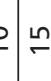 & $\sim$ & 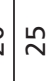 & m & $m$ & 아 & 牢 \\
\hline
\end{tabular}




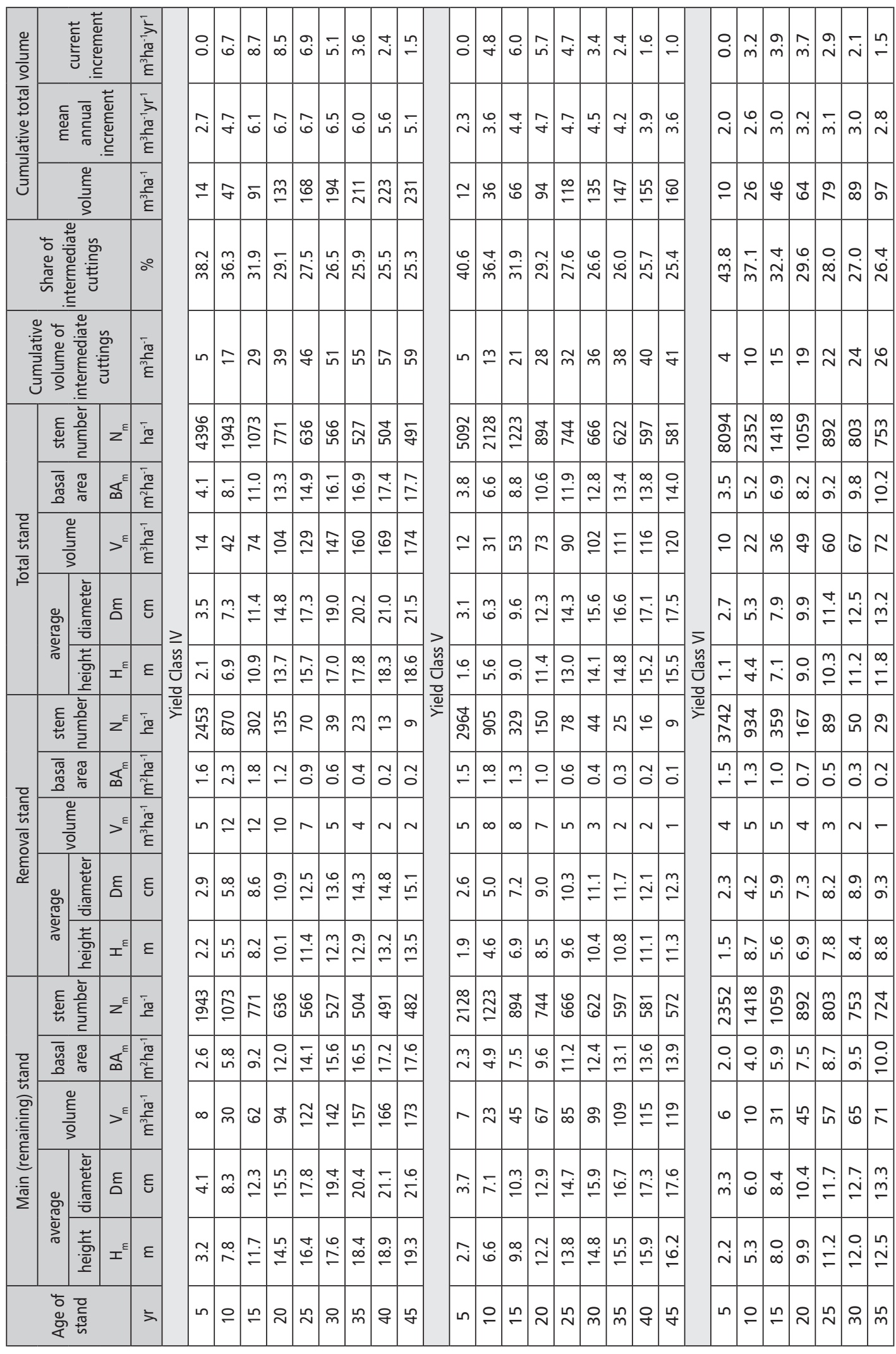




\section{REFERENCES}

1. KOPECKY F 1962 Poplar breeding. In: Keresztesi B (ed) Poplar Growing in Hungary. Mezógazdasági Kiadó, Budapest, pp 83-117

2. KOPECKY F 1978 Cross-breeding. In: Keresztesi B (ed) Poplar and Willow Growing. Mezógazdasági Kiadó, Budapest, pp 47-65

3. RÉDEI K 1991 Improvement of Leuce-poplars growing in Hungary. Erdészeti Kutatások 83: 304-312

4. RÉDEI K 1994 Yield of promising P. alba provenances on the Danube-Tisza region sands. Erdészeti Kutatások 84: 81-90

5. RÉDEI K 2000 Early performance of promising white poplar (Populus alba) clones in sandy ridges between the rivers Danube and Tisza in Hungary. Forestry 73 (4): 407-413

6. SOPP L, KOLOZS L (eds) 2000 Volume Tables. ÁESZ, Budapest, pp 58-64
7. HUSCH B, MILLER C I, BEERS T W 1982 Forest Mensuration. Ronald Press, New York

8. AVERY T E, BURKHART H E 1994 Forest Measurements. $4^{\text {th }}$ ed. McGraw-Hill, Inc., New York

9. LAAR A, AKCA A 1997 Forest Mensuration. Cuvillier Verlag, Göttingen

10. RÖHLE H 1999 Datenbank gestützte Modellierung von Bestandesköhenkurven. Cbl für das ges Forstwesen 116 (1-2): 35-46 (in German).

11. PRETZSCH H 2009 Forest Dynamics, Growth and Yield. Springer

12. RÉDEI K 2003 Black locust (Robinia pseudacacaia L.) Growing in Hungary. Publications of the Hungarian Forest Research Institute, Budapest, p 70

13. RICHARDS F J 1959 A flexible growth function for empirical use. Journal of Experimental Botany 10: 290-306 